\title{
The Jardin - Anglais as Public Image of the Self
}

\author{
Janet R. White \\ School of Architecture, University of Nevada, USA
}

Copyright $₫ 2017$ by authors, all rights reserved. Authors agree that this article remains permanently open access under the terms of the Creative Commons Attribution License 4.0 International License

\begin{abstract}
At first glance, the jardin-anglais of $18^{\text {th }}$-century France appears to be composed of a standard set of pieces. A closer examination of specific gardens, however, reveals that elements were often chosen in order to "fit" the garden to the patron. These choices were intended to make each garden into a kind of portrait of its owner, an important means of projection of self to others. Three gardens are examined here: Marie Antoinette's at the Petit Trianon at Versailles; the Desert d' Ermenonville, the garden of the Marquis de Girardin; and Monsieur de Monville's Desert de Retz. A "close reading" of features of each reveals that each plays on the standard repertoire to turn the garden into a public self-portrait of its creator as he or she wished to be seen. They add up to three very different public images of the self-projected by three gardens with very different atmospheres. The new innate self of the second half of the eighteenth century was to be "cultivated by a spontaneous relation to nature" [1]. It is perhaps not surprising then to find nature as expressed in the garden being in turn made into the means of projecting the self to others.
\end{abstract}

Keywords Eighteenth-century, Jardin - Anglais, French Gardens

\section{Introduction}

At first glance, the jardin-anglais of $18^{\text {th }}$-century France appears to be composed of a standard set of pieces. It consists of a series of picturesque scenes upon which the visitor comes as he or she moves around the garden or estate. These scenes, accented by architectural follies, are intended to evoke an emotional response in the viewer, for the viewer's entertainment. By the mid- $18^{\text {th }}$ century, the scorn of the rational $17^{\text {th }}$ century towards the passions was replaced "by an exaltation of strong emotions" [2] and the jardin-anglais fed this taste. A good garden design would provide variety, with elements evoking Edmund Burke's Beautiful and Sublime emotions, a sense of the Exotic and the more familiar Rustic. Classical architecture and still water were associated with the Beautiful, while Gothic architecture and the wilder manifestations of Nature were assigned to the Sublime.

In the French examples built during the reign of Louis XVI (1774-1792), more so than in the original English versions, certain elements consistently appear: there are the Beautiful round temple and theater; the Sublime grotto, tomb and Gothic ruin; the Exotic pavilion; the Rustic ferme orneé and hermitage. A closer examination of the details of specific gardens, however, reveals that choices of elements and adaptations of the standard forms were often made in order to "fit" the garden to the patron or creator and create an atmosphere specific to that garden. As Jean A. Perkins [2] puts it in The Concept of Self in the French Enlightenment, after 1750 one could look on the self as a "creature of sentiment" but also as "an active member of society," and in the latter case "it is the means by which one projects one's self-image to others that are important". This paper argues that these choices among and adaptations of the standard elements were intended to make each garden into a kind of portrait of its owner, an important means of public projection of self-image to others. Like the work of Stephen Bending [3], it is based on the assumption that "the shaping of physical space is the shaping also of identity, and that gardens are microcosms" which not only, in Bending's words, are "speaking of and reacting to a world beyond themselves" but, I would add, are speaking to that world.

Three gardens outside Paris and dating from the decades before the Revolution will be examined in detail: Marie Antoinette's garden at the Petit Trianon at Versailles, begun in 1774; the Desert d'Ermenonville, which is the garden of the Marquis de Girardin and was begun soon after he inherited the estate in 1763; and Monsieur de Monville's Desert de Retz, for which construction of the first folly began in 1777. A "close reading" of the follies and features of each garden reveals that each plays on the standard repertoire to turn the garden into a public self-portrait of its creator as he or she wished to be seen.

\section{Marie Antoinette's Garden at the Petit Trianon, Versailles}

The original plan of the Queen's garden at Versailles was 
developed by the Comte de Caraman, an amateur gardener, in 1774, but many hands had input into the design, including Richard Mique, the Queen's architect, who prepared a new plan in 1777, (Figure 1) and the painter Hubert Robert, whom the Queen consulted on issues such as the artistic placement of rocks on the Temple of the Sybil at Tivoli. The difference lies in the dedications, and here the Temple, one of the first elements of the garden and placed axially before the Trianon's windows where the Queen could see it from her bedroom, is dedicated to Love.

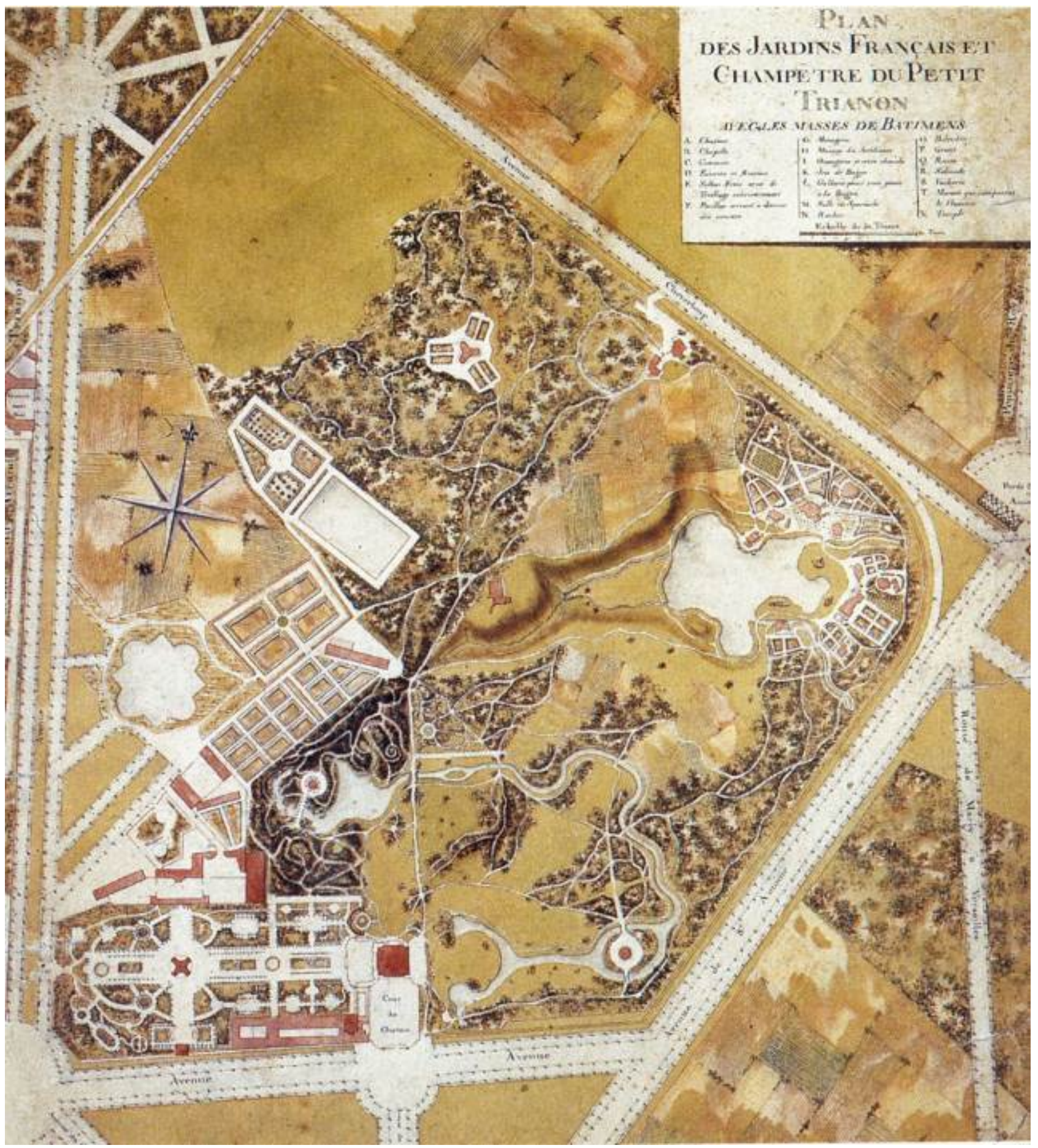

Dams and Zega, p. 113

Figure 1. Plan of Marie Antoinette's garden at Versailles 
With any design there is always the question of the degree of involvement of the patron in design decisions. We have evidence that the Queen was very personally involved in the design of her new garden. The designs of the follies were modified many times, and it was the Queen who chose to eliminate some of those proposed [4]. For the various elements of the design, the designers made very precise models and presented them to her [4]. Five models of the Belvedere were shown to the Queen before she approved one [5], seven models were made of the Grotto designs for her to choose among [6] and she looked at fourteen versions of the Rocher before selecting the final design [4]. When commissioned to design a permanent theater Mique presented an elaborate model in gilded wax with blue silk and velvet curtains illuminated by twenty-four little lamps, while the decorators presented motifs in clay or plaster. We are told by de Nolhac [4] that the Queen examined them and decided the least details of the theater's decor. This close attention was in the service of an image - an image of Marie Antoinette as the young, gay (in the old sense), and stylish Queen of Love. The details of the garden support this position.

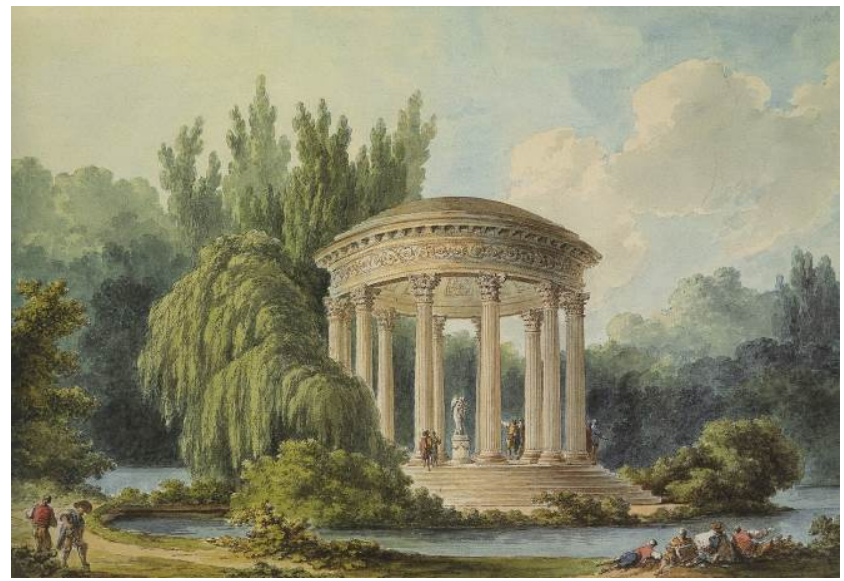

Arizzoli-Clementel, Pierre. Views and Plans of the Petit Trianon at Versailles. Alain de Gourcuff Editeur, Paris, 1998, p. 90

Figure 2. Marie Antoinette's Temple of Love

The Beautiful is well represented in the Queen's garden by the Temple of Love, (Figure 2) inaugurated in September 1778, and the Belvedere, completed in 1781. All three of the gardens discussed here have a round tholos temple modeled

The motifs used in the decoration of the Belvedere's walls further support the notion that the Queen wanted her garden to project a image of a joyous, playful queen of love. They include entertaining motifs such as a monkey trying to get fish out of a crystal vase and emblems of love, like flying doves and hearts pierced by arrows.

The tone everywhere is light and joyful. In Marie Antoinette's garden we find no ruined Gothic, no tomb designed to evoke Sublime melancholy.

The original design had proposed a ruined temple on a big rock surrounded by debris supposedly fallen from its facades, but the Queen rejected it. A hermitage likewise was proposed and rejected [4]. Their dark implications of Sublime melancholy and solitude did not fit the image the Queen wanted to project.

When the Sublime does appear, it is tamed by pairing with the Beautiful; the main grotto, the Rocher du Belvedere, sits next to and forms the approach to the elegant music pavilion, the Belvedere itself (Figure 3).There was also a second grotto described as "this mysterious retreat" [6] by a $19^{\text {th }}$ century visitor that is so dark that the eyes "needed a certain time to discern objects within." It contains a bed covered in moss that "invites one to repose" and from which one can conveniently see through a crevasse anyone who is approaching. It is as if the grotto were designed for flirtations and stolen kisses - a narrow staircase led out the back and permitted, says de Nolhac, "the indiscrete to steal away" [4]. Even the Sublime is turned to the service of Love.

The Exotic is represented by stylish Chinoiserie: a Chinese room in the upper floor of the Queen's House at the Hameau and a Chinese carousel on which a game could be played, of tilting at the ring. This was a game which required display of grace and dexterity, again emphasizing youth and playfulness.

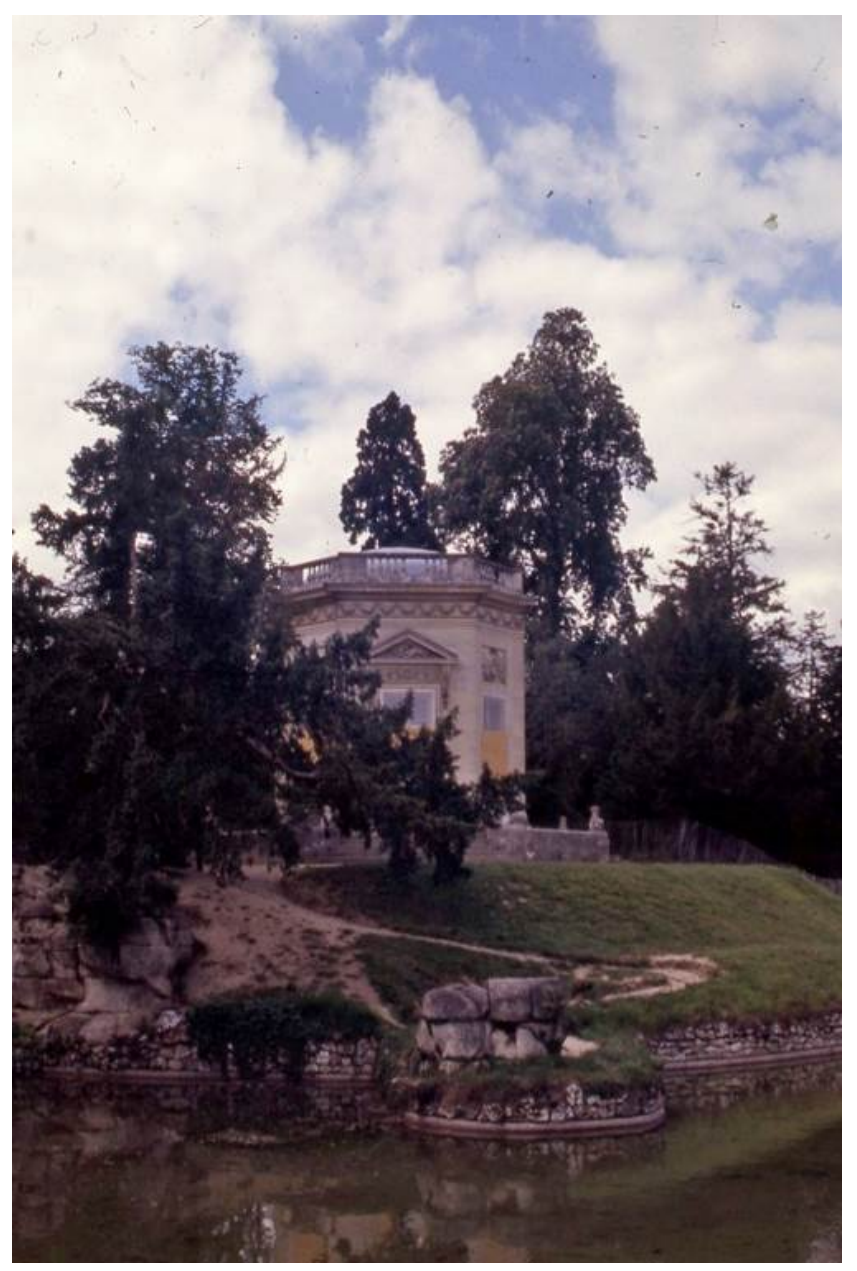

Photo by author

Figure 3. The Belvedere

The Rustic is in full bloom here with the famous Hameau, begun in 1783. It was Hubert Robert who first formulated the 
idea and Richard Mique who did the design and prepared the models for the Queen's approval. Twelve buildings set around an artificial lake, it was part playground and part working farm. The two principal buildings contained first what was called the "Queen's house" with a ground floor dining room and backgammon room; the second, attached to it by a gallery, contained a billiard room. Smaller buildings around them with thatched roofs housed such functions as a boudoir for the Queen and a kitchen equipped with bake house, linen closet and silver hutch and a separate room for the footmen. The barn was used as a ballroom. The rustic appearance, reminiscent of Normandy farmhouses, was not continued on the interiors, where courtly elegance took over. The boudoir house had Dutch oak paneling and Bohemian glass window panes [4]. Even the mill, which actually ground grain for the use of the Hameau's working inhabitants, contained an elegant room with mirrors and a white marble chimney [4].

A little distance away, the actual farm buildings stood around a court planted with trees. They included separate stables for different kinds of animals, a now demolished working dairy and barn, and housing for those who actually worked the farm and cared for the animals. The ferme ornée, a a picturesque but working farm incorporated into the ornamental gardens of an estate, was a relatively common feature of the $18^{\text {th }} \mathrm{c}$, landscape - de Nolhac [4] tells us that "everyone, in the $18^{\text {th }} \mathrm{c}$, was interested in the country inhabitants" and "every fortunate bourgeois wanted to make a ferme ornée part of his leisure activities and occupy himself, like a good philosophe, with the happiness of his country folk". But the Queen's ferme ornée had nothing of the scientific experimentation aspect that was sometimes associated with this phenomenon - it was a playground, with a washed white cow brought to the marble paneled space designated as the Dairy of the Queen (as distinct from the working dairy) so the Queen and her ladies could play at being milkmaids and drink fresh milk and amuse themselves by churning butter in porcelain churns marked with the royal insignia. So the Rustic elements too are part of the image - playful, not serious agricultural experimentation, filled with elegant game rooms and dining facilities.

One might raise the question of whether this was a conscious image -- the way she wanted to be seen. Her behavior towards the garden justifies such a claim. When foreign princes came to Paris she invited them to the garden; if they were incognito, de Nolhac [4] tells us, "for a simple visit, which she guided herself". When her brother Emperor Joseph II visited he was so taken by the garden he wanted complete plans of the garden and buildings. "The
Queen took an interest in the work and wanted to send the plans to him herself"[4]. On several occasions she had albums made with a collection of views of the Petit Trianon and the gardens which were given as souvenirs of visits, indicating that this was the image she wanted to have remembered.

We should note that the particular self-image projected was daring and not well advised. She had herself painted in the garden in the costume she often wore at the Trianon, a simple dress of white muslin and a straw hat. The portrait was shown in the Salon of 1783 and caused a scandal because of its casualness and lack of majesty - it was said she was dressed like a "femme de chambre." The portrait had to be withdrawn from the exposition.

\section{The Désert d'Ermenonville}

The Désert d' Ermenonville presents a 180 degree turn in image projection. The Marquis de Girardin, serious philosophe and student of Jean Jacques Rousseau, dedicated his tholos temple to Modern Philosophy, complete with unmarked columns awaiting the names of geniuses of the future. The image is one of serious thoughtfulness. To underline the seriousness of the endeavor, nearly every folly carries its quotation from the philosophers or other ancient and modern writers. That not being enough for him, he wrote his own treatise on garden design, An Essay on Landscape (De la Composition des paysages 1777). To be sure nothing is missed, a bench was placed at every point where the visitor was to stop and take in the scene [7]. Each piece of the garden is to be regarded, he says, as "a little easel picture in a gallery" and the one who composes it must be a "poet and painter" [8]. It is clear that Girarden was personally responsible for overseeing the master plan of the estate after he inherited it in 1762 [9]. He was acknowledged as its author by his contemporaries; Jean-Marie Morel was his technical consultant and designer of some of the individual structures.

At the same time, the Beautiful is not ignored; there is an arcadian prairie with a recreation of the cabin of Ovid's Philemon and Baucis, an obelisk dedicated to four pastoral poets in four languages, a Temple of Bacchus, and the aforementioned Temple to Modern Philosophy placed atop the highest hill (Figure 6). Its pillars are consecrated to the memory of Isaac Newton, René Descartes, Voltaire, William Penn - for his status as humanitarian - Montesquieu, and, of course, Jean-Jacques Rousseau. The Beautiful too is thus given a serious, scholarly aspect. 


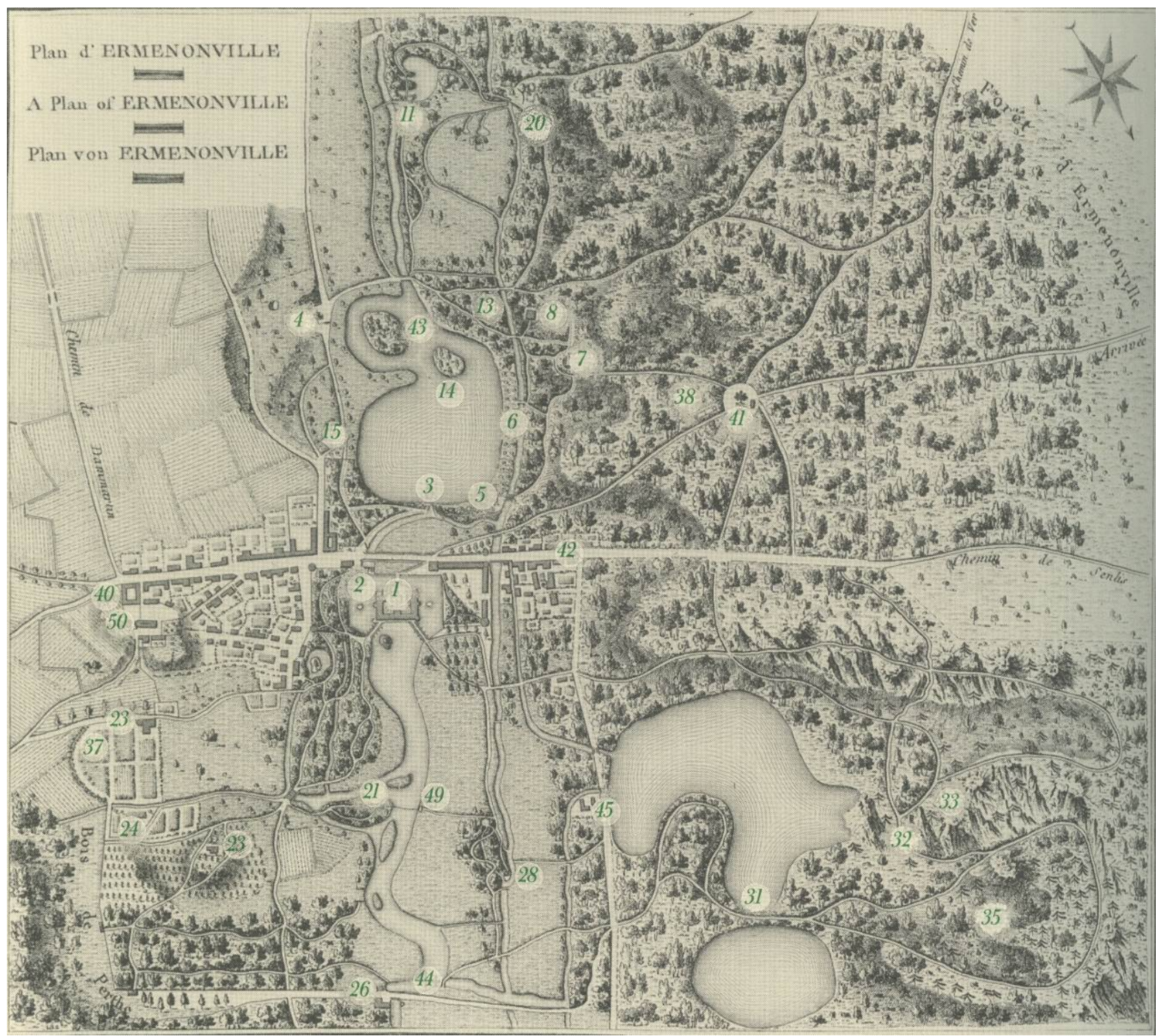

Laborde, Comte Alexandre de, p. 95

Figure 4. Plan of Ermenonville

The Marquis de Girardin's garden, at over 2,000 acres, is by far the largest of the three discussed here (Figure 4). Its many features were mostly Sublime and Rustic, evoking the landscapes of Rousseau's La Nouvelle Heloise. There is little of the frivolous Exotic here. Even exotic plants are forbidden - "Nature," he believes, "has planted everything in the situation which is best adapted to it" and foreign trees "seldom accord well with the trees of the country" \{8]. The only Exotic touch is an Indian tepee - which is no doubt intended to evoke thoughts of the Noble Savage in Nature.
The list of Sublime features includes a cascade and accompanying grotto "with an air of decay" that brings "the spirit to a sweet and tender melancholy"[7], three additional grottos, an altar dedicated to meditation, a marble funerary urn with verses of Petrarch, a Gothic building housing the gardener, and surely the ultimate in Sublimnity, the actual tomb of Jean-Jacques Rousseau himself, designed by Hubert Robert and placed on an isle surrounded by poplars (Figure 5 ). There is plenty of prompting for the serious, darker emotions here - and for a view of the owner as a serious man. 


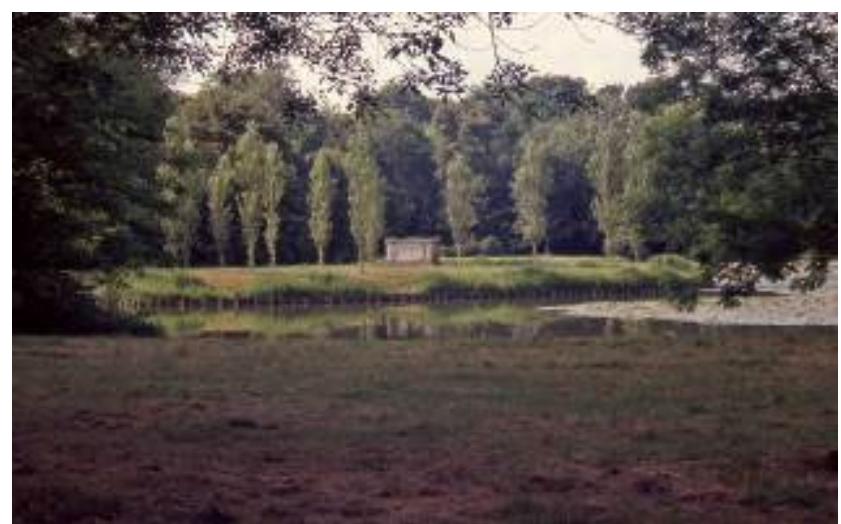

Photo by author

Figure 5. Tomb of Jean-Jacques Rousseau

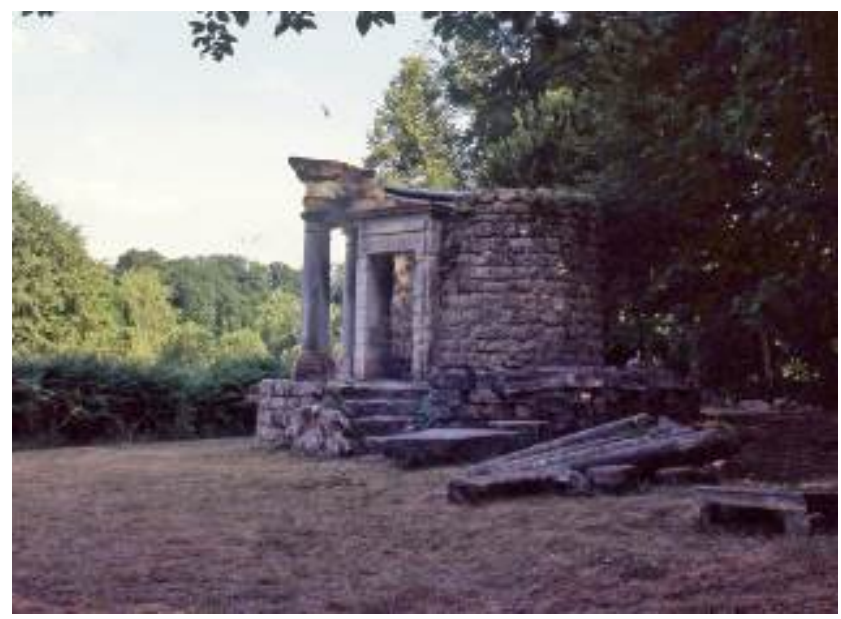

Photo by author

Figure 6. The Temple of Philosophy

The long Rustic list begins with an Italian mill and includes both an Hermitage and a Rustic temple with thatched roof and tree-trunk columns. There is a cabin built of reeds. Another of rocks covered with thatch called Jean Jacques' cabin with inscriptions from Rousseau, a fisherman's house by the lake. Love has its place here too, but instead of a beautiful classical temple, the altar dedicated to love is a "rough unfinished stone" with "this is the domain of Love" carved on one side. The influence of La Nouvelle Heloise is clear; this is a spot for Julie to meet her love in Nature.

But Girardin's evocation of the Rustic did not stop with follies á la Rousseau. He had an actual hameau on his estate. The land closest to this village he divided into small farms, which according to his son he intended to give to "the most virtuous of the parish" [7] and then establish a prize for agricultural experimentation on them. In his Essay on Landscape he writes that he believes the style of picturesque gardening he espouses will attract citizen farmers who "by improvements, the result of their reflections and experience, very much contribute to the advancement of agriculture" [8]. The Italian mill is picturesque, but also uses the most perfected milling system of the time. His ferme, not even very ornée, is to be a true model farm, site of genuine social concern and serious scientific work, as behooves that of a philosophe.

Laborde [10] thought Ermenonville was "one of the finest places in France", but in his efforts to project a sensitive, serious, scholarly and philosophical image, many visitors thought de Girardin overdid it. In the end there were nearly fifty items that the visitor should take note of listed on the general plan of the estate. One author opined that "everything tends to create the same effect of kitsch" [11] though admitting that the effect was lessened because of being spread over such a large expanse. The constant inscriptions carved into every feature and folly, in particular, annoyed - the Prince de Ligne called them "trivial or pedantic or unfortunate or innumerable or ill-sited" and said none "was able to satisfy the demands of this beautiful location" [11]. Nevertheless, the garden was famous in its time and much visited, by notables' figures as diverse as Benjamin Franklin [12] and the Queen.

\section{The Désert de Retz}

Unlike the creators of the previous two gardens discussed, Francois Racine de Monville was not an aristocrat. He moved in aristocratic circles, however, a one-time lover of Madame du Berry, and a companion of the Duc d'Orléans. The Comte de Tilly, who stayed at le Désert, wrote of him that he was "totally unlike a financier except for wealth" and that he possessed "the qualities required to live exclusively amongst the most distinguished persons of their time in all conditions, and to meet with their approval."[13] The grandson of a Farmer General and son of a General Tax Collector, he inherited a large income at the age of thirty which allowed him to begin a "new career as an ornament of society [14]. He is described by one biographer as having had "an epicurean view of life" and having contracted many liaisons with actresses of the Opera and dancers at the Comedie Francais, as well as with women of society [15]. Madame de Genlis described him in her Memoires as "a magnificent lover, a rich young widower, and very handsome, noble and romantic" [16], the very image which his garden of Le Désert created (Figure 7). 

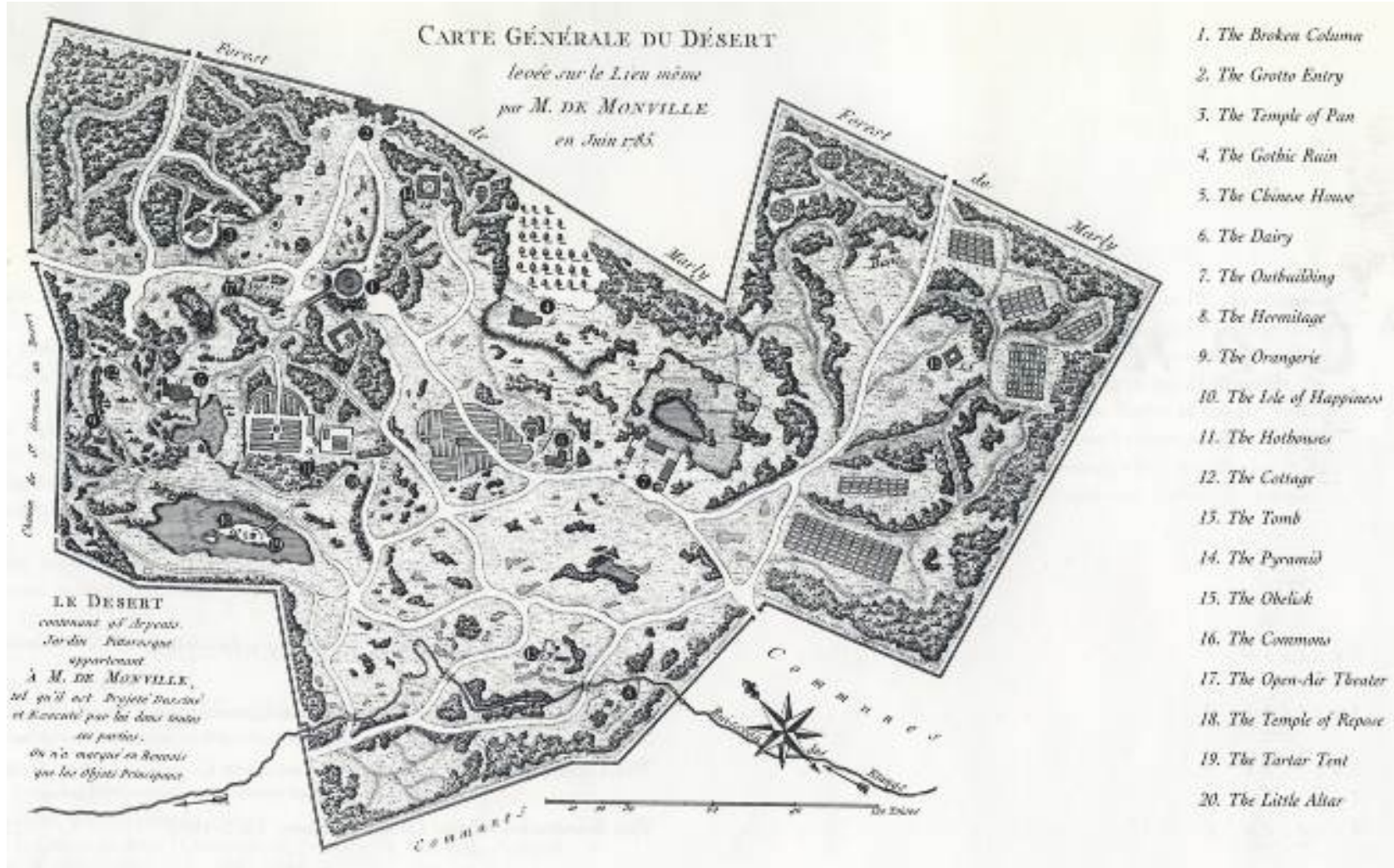

GENERAL MAP OF THE DÉSEgT DE RETZ

Le Rouge, G.L. Jardins anglo-chinois a la mode. Cahier XIII Paris 1785

Figure 7. Plan of the Desert de Retz

The extent to which de Monville was responsible for the design of the garden and its fabriques has been questioned, with attributions being made to Boullée, Hubert Robert and others. Ketcham [14], however, presents evidence from a 1780 lawsuit which indicates that de Monville worked cooperatively with an architectural student named François Barbier on the designs of the follies. She states that the proceedings of the lawsuit show that "the usual procedure was for de Monville to make sketches that Barbier rendered into finished drawings or clay models, though in some instances Barbier's models came first". For the gentleman of leisure that de Monville was, untrained in architecture, such a procedure would have been an effective way of refining and implementing his ideas. Moreover, his residential pavilion at the Désert included a studio with a forge and cabinetmaker's bench where he made models himself and kept, among other treasures, an eight by twenty-two feet relief model of the estate [14]. The evidence leaves no doubt that de Monville, while he may not have been the originator of every concept, was deeply involved in the design process.

De Monville began with the Exotic - the first construction on the site, in 1777-78, was a two story teak Chinese Pavilion which was initially his residence when he visited the garden. In this he showed himself to be a man of fashion; Dams and Zega estimate that several hundred Chinese pagodas were built in France in the decades before the Revolution [16]. This fashion did not outlast the
Revolution; Laborde, writing in 1808, described the Chinese pavilion as an "instance of the bad taste which then reigned, and of the expense made in this detestable kind of magnificence" [10]. But he also demonstrated that he was a man of imagination - a second Exotic element, a Tartar Tent, graced a small island. The evocation of the frightening Tartars, or Huns, is a unique way of inducing that delightful frisson of terror that is the goal of the Sublime.

There is a nod to the Beautiful: two Classical temples, one a delicate tholos; a Roman urn; an open air theater. There is a Rustic hermitage and a ferme ornée, in this case a rather pragmatic farmstead and orangerie that produced foodstuffs and flowers for the villa. The farm and a maison bourgeoise which had existed on the property when he purchased the land were simply given new names - "Laitierie" and "Métarierie Arrangée" [17].

Many of the twenty follies, however, fall into the Sublime category: a ruined gothic chapel - he was lucky enough to have access to a real one (Figure 8); an empty tomb ominously awaiting an occupant; a Roman altar in ruins; a mysteriously Masonic pyramid. The mood is one of romantic mystery and dark powerful emotions.

The central element and pièce de résistence is the residence pavilion of about 1781. It is a circular structure fifty feet in diameter and stands fifty-five feet high, with a jagged roofline and fluting that appears to be the stump of a gigantic broken column. An elegant four-story residence is 
fitted into the round floor plan, around a central spiral staircase. It is gigantic rather than miniaturized like the typical fabrique and, as John Dixon Hunt suggests, evokes the Sublime in the dimensions of both time and space [12]. Grand, striking, mysterious and a little melancholy, the Broken Column is as handsome and romantic as the young widower himself.

There is even a strong suggestion of a darker thread running through the image. The entrance to the estate is through a grotto, so one's initial experience is to go underground, into the dark. His tholos temple is dedicated to the satyr god Pan. Moreover, the published image of his entry grotto shows two satyrs holding flaming torches (Figure 9); although it isn't clear whether these were a permanent installation. Are we not to infer certain wildness, a suggestion of unbridled sexuality? The pavilion in the garden as a type also had a certain libertine sexual association, having been the preferred place of rendezvous for royal mistresses from the time of Louis XIV. Ketcham [14] points out that de Monville "would have known the royal pavilions and their role as maisons de rendez-vous". His choosing to build first the Chinese Pavilion and then the Broken Column at his garden retreat to serve as residences further suggests an underlying thread of sexuality in his projected self-image.

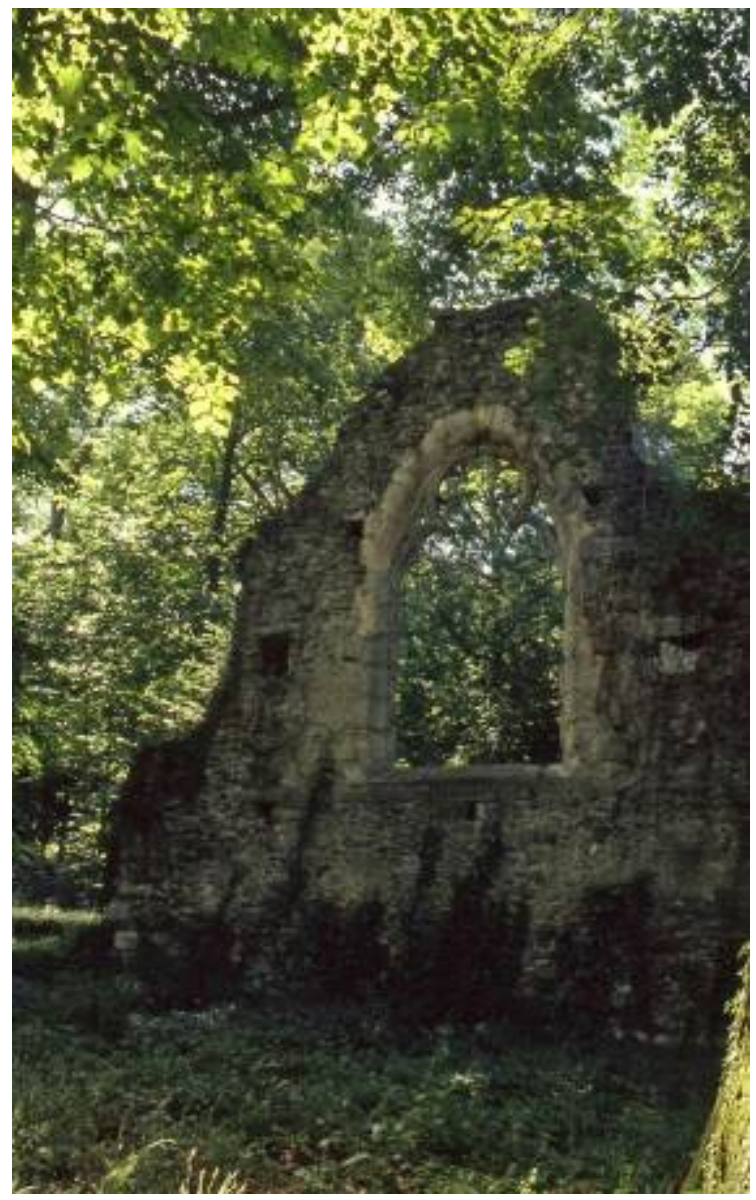

Photo by author

Figure 8. Gothic ruin at Le Desert de Retz

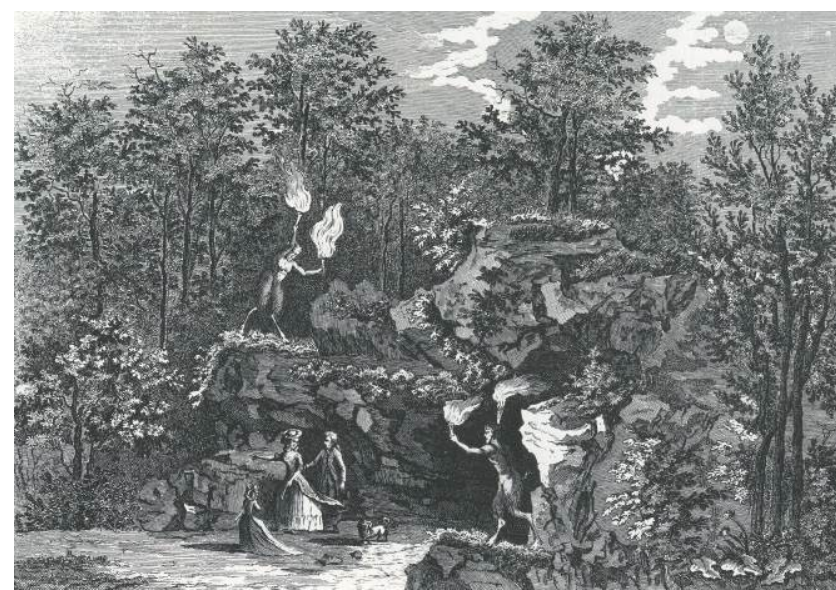

Le Rouge, G.L. Jardins anglo-chinois a la mode, Cahier XIII Paris 1785

Figure 9. Entry grotto to the Desert de Retz

That this was a public image is clear. While the jardin-anglais functioned as a retreat, at the same time these parks were "private space visited by the public" and "public space shaped by a private individual" [3]. The Queen herself visited the Désert, as did King Gustavus III of Sweden and Thomas Jefferson, but its visitors were not only persons of rank and importance. Ordinary citizens could receive a ticket at the gate provided only "those visitors be decently dressed" [14].

Francois de Monville may have come to regret the somewhat libertine image he constructed of himself through his garden. He was evidently successful in projecting a public image of himself as a roué. In May, 1794, he was denounced by a Revolutionary Tribunal, arrested, and barely escaped with his life. The charges included "sybaritisme" and having been the "companion in pleasure" of the infamous Duc d' Orleans [15].

\section{Conclusions}

It is evident that these gardens are not all alike, that choices made by the patrons were intended to create a particular atmosphere which in turn projected a particular image of the patron themselves. Ego-assertion and projection is one of the major themes of $18^{\text {th }} \mathrm{c}$ French fiction; its characters are "strongly motivated by a desire to impose their view of themselves on society" [2]. While one cannot always argue from literary examples, this suggests a similar desire among the readers of the literature to project on society their views of themselves.

Perhaps the most telling example of this desire to impose a particular view of them is the variety of dedications of the ubiquitous tholos. Marie Antoinette, young and lovely queen of the court, dedicated her round temple to Love. The philosophe Marquis de Girardin left his temple to Modern Philosophy unfinished to allow for the addition of future sages. Mon. de Monville, the romantic ladies' man, dedicated the tholos at the Désert de Retz to the satyr Pan. In 
each case, the dedication evokes and publicizes an association desired by the patron. Other details add to the desired public image - whether there is a tomb and who is buried in it, the use made of the ferme ornée, the type of Exotic pavilion included, or the presence or absence of a hermitage.

That the image was a public one is also clear. While the gardens served as places of retreat, of relief from the rigidities of court life and the demands of society, society also came to view them. The gardens of Versailles were open to any party in which the gentlemen were wearing swords, and enterprising vendors rented them to the swordless outside the garden gates. Tickets to visit Marie Antoinette's garden could be issued to "properly dressed people" by her concierge when she was not there [5]. The supposed excesses of the Queen's Hameau were known and contributed to the royal downfall. By 1788, a guidebook had been published that led visitors through the grounds of Ermenonville, and Mon. de Monville's issuing tickets to anyone decently dressed who came to his gates has been noted above.

Together, the details add up to three very different public images of the self-projected by three gardens with very different atmospheres. As John O. Lyons [1] says in his The Invention of the Self, the new innate self of the second half of the eighteenth century was to be "cultivated by a spontaneous relation to nature". It is perhaps not surprising then to find nature as expressed in the garden being in turn made into the means of projecting the self to others. It might even be argued that the popularity of the jardin-anglais among wealthy French patrons before the Revolution was in part due to the opportunities the garden offered for creating a public image of the self.

\section{REFERENCES}

[1] Lyons, John O. The Invention of the Self: the Hinge of Consciousness in the Eighteenth Century. Southern Illinois University Press, Carbondale, IL 1978.

[2] Perkins, Jean A. The Concept of the Self in the French Enlightenment. Librairie Droz, Geneva, 1969.
[3] Bending, Stephen. Green Retreats: Women, Gardens and Eighteenth-Century Culture. Cambridge UP, Cambridge, 2013.

[4] de Nolhac, Pierre. Le Trianon de Marie-Antoinette.: Calmann- Levy, Editeurs, Paris, 1924.

[5] Duvernois, Christian. Marie-Antoinette and the Last Garden at Versailles. Rizzoli International Publication, Inc., New York, 2008.

[6] Choffé, Laurent. Le jardin Champêtre de Trianon: l'alliance $\mathrm{du}$ pittoresque à la botanique. (The Jardin Champetre of the Trianon: the alliance of the picturesque and the botanical). Versalia Vol. 7, 56-69. 2004.

[7] Merigot, J. Promenade ou Itineraire des Jardins d'Ermenonville. Merigotpere, Librairie, Paris, 1788.

[8] Girardin, René Louis, Marquis de. Composition des paysages. Geneva. (An Essay on Landscape). 1777. fasc. trans. Garland Publishing, Inc., New York and London, 1982.

[9] Wiebenson, Dora. The Picturesque Garden in France. Princeton University Press, Princeton, NJ, 1978.

[10] Laborde, Comte Alexandre, de. Description des Nouveaux Jardins de la France et de ses Anciens Chateaux .... L' Iprimerie de Delance, Paris, 1808.

[11] Ligne, Charles-Joseph, Prince de. Coup d' oeil at Beloeil and a Great Number of European Gardens. 1795. trans. and ed. Basil Guy. U of CA Press, Berkeley and Los Angeles, 1991.

[12] Hunt, John Dixon. The Picturesque Garden in Europe. Thames \& Hudson, Ltd., London, 2002.

[13] Tilly, Comte Alexandre de. Memoirs of the Comte Alexandre de Tilly.1828 (?).Trans. Françoise Delisle. Farrar \& Rinehart, Inc., New York, 1932.

[14] Ketcham, Diana. Le Désert de Retz. A Late Eighteenth-Century French Folly Garden, The Artful Landscape of Monsieur de Monville. MIT Press, Cambridge, MA, 1994.

[15] Dach, Michel. Le Désert de Retz a la lumiere d'un angle particulier. : Michel Dach, Rocquencourt, FR, 1995.

[16] Dams, Bernd H., and Zega, Andrew. Pleasure Pavilions and Follies in the Gardens of the Ancien Régime. Flammarion, Paris and New York, 1995.

[17] Renard, Pierre-Emile. Chambourcy et le Désert de Retz. Association Histoire de Chambourcy, Chambourcy, FR, 1984. 